\title{
Identifikasi Penentuan Prioritas Kriteria Kawasan Permukiman Kumuh Perkotaan Menggunakan Metode AHP (Analytical Hierarcy Process)
}

\author{
Hafsah Fatihul Ilmy dan Yanto Budisusanto \\ Jurusan Teknik Geomatika, Fakultas Teknik Sipil dan Perencanaan, Institut Teknologi Sepuluh Nopember (ITS) \\ Jl. Arief Rahman Hakim, Surabaya 60111 Indonesia \\ e-mail: yanto.budisusanto@gmail.com
}

\begin{abstract}
Abstrak-Kota metropolitan yang berkembang di Indonesia tidak dapat menghindar dari masalah-masalah yang berkaitan dengan permukiman kumuh. Masalah permukiman kumuh biasanya dikarakteristikan dengan menurunnya kondisi lingkungan seperti masalah keterbatasan ketersediaan air tanah dan perdampahan. Berdasarkan fakta fakta tersebut, penelitian ini bertujuan untuk mengidentifikasi dan mengklasifikasi kawasan permukiman kumuh perkotaan. Dalam menentukan prioritas kriteria kawasan permukiman kumuh perkotaan dilakukan penentukan bobot prioritas kriteria-kriteria yang berpengaruh terhadap kekumuhan menggunakan analisis AHP. Adapun kriteria-kriteria yang sangat berpengaruh terhadap penentuan identifikasi kawasan kumuh di wilayah penelitian, yaitu kriteria sistem pengelolaan persampahan tidak sesuai standar teknis, tidak terpeliharanya sarana dan prasarana persamapahan, tidak terpenuhinya kebutuhan air minum, cakupan pelayanan jalan lingkungan dan ketidaktersediaan drainase.
\end{abstract}

Kata Kunci-AHP, Kekumuhan, Kriteria Kawasan Kumuh

\section{PENDAHULUAN}

$\mathrm{K}$ AWASAN permukiman kumuh adalah lingkungan hunian yang mengalami penurunan kualitas fungsi sebagai tempat hunian, ciri-cirinya antara lain berada pada lahan yang tidak sesuai dengan peruntukan/tata ruang, kepadatan bangunan sangat tinggi dalam luasan yang sangat terbatas, rawan penyakit sosial dan penyakit lingkungan, serta kualitas bangunan yang sangat rendah, tidak terlayani prasarana lingkungan yang memadai dan membahayakan keberlangsungan kehidupan dan penghidupan penghuninya [1].

Bagi kota yang mulai padat penduduknya, pertambahan penduduk tiap tahun jauh melampaui penyediaan kesempatan kerja di dalam wilayahnya sehingga dirasakan menambah berat tekanan permasalahan di kota-kota besar. Tekanan ekonomi dan kepadatan tempat tinggal bagi kaum urban memaksa mereka untuk menempati daerah-daerah pinggiran (slum area) hingga membentuk kawasan Permukiman kumuh [1].

Di dalam tahapan penanganan kawasan kumuh, UU No. 1 Tahun 2011 tentang perumahan dan kawasan permukiman mengamanatkan pemerintah kabupaten/kota dalam melaksanakan pembinaan memiliki tugas: (i) menyusun rencana pembangunan dan pengembangan perumahan dan kawasana permukiman (RP3KP), (ii) menyusun rencana kasan permukiman (RKP) sebagai pelaksnaan tahapan perencanaan dalam penyelenggaraan permukiman, dan (iii) menetapkan kawasan perumahan/permukiman kumuh berdasarkan indikator dan kriteria sesuai karateristik di wilayahnya masing-masing. Dengan adanya peraturan tersebut perlu dilakukan adanya identifikasi wilayah kumuh oleh karnanya diperlukan pembuatan peta lokasi kawasan kumuh perkotaan. Dalam pembuatan peta kawasan kumuh perkotaan sebelumnya diperlukan penentuan kriteria kawasan permukiman kumuh perkotaan yang kemudian dilakukan identifikasi penentuan prioritas kriteria kawasan permukiman kumuh perkotaan menggunakan metode AHP (Analytical Hierarchy Process).

\section{METODOLOGI PENELITIAN}

\section{A. Metode Pengumpulan Data}

Dalam proses pengumpulan data, proses ini dilakukan dengan wawancara pada stakeholder dan studi literatur. Adapun wawancara pada stakeholder yang dimaksud adalah untuk menentukan prioritas kriteria-kriteria kekumuhan. Studi literatur atau kepustakaan yang dilakukan dengan meninjau isi dari literatur yang bersangkutan dengan tema penelitian ini, diantaranya berupa buku, hasil penelitian, dokumen rencana tata ruang, penelitian serta artikel di internet.

\section{B. Metode Analisis}

Dalam proses penentuan identifikasi kawasan permukiman kumuh perkotaan maka diperlukan beberapa tahapan analisis, adapun tahapan analisis tersebut adalah sebagai berikut:

1. Analisis penentuan bobot prioritas kriteria-kriteria yang berpengaruh terhadap kawasan permukiman kumuh di wilayah penelitian.

Kriteria-kriteria yang berpengaruh terhadap kawasan permukiman kumuh ditinjau dari teori-teori terkait permukiman kumuh. Dalam analisis kriteria-kriteria yang berpengaruh terhadap identifikasi kawasan permukiman kumuh digunakan alat analisis AHP (Analytic Hierarchy Process). Analisis AHP digunakan untuk menentukan bobot tiap kriteria-kriteria yang 
berpengaruh terhadap identifikasi wilayah permukiman kumuh. Dalam analisis ini digunakan alat pengolahan untuk analisis AHP.

\section{HASIL DAN PEMBAHASAN}

\section{Analisis penentuan bobot prioritas kriteria-kriteria yang berpengaruh terhadap kawasan permukiman kumuh.}

Berdasarkan hasil dari tahapan analisis yag telah dilakukan, yaitu analisis AHP (Analytic Hierarchy Process), diperoleh kriteria-kriteria yang berpengaruh terhadap identifikasi kawasan permukiman kumuh. Berikut ini merupakan tabel kriteria-kriteria yang berpengaruh terhadap identifikasi kawasan permukiman kumuh di wilayah penelitian dapat dilihat pada tabel 1.

Tabel 1.

Kriteria-Kriteria yang Mempengaruhi Identifikasi Kawasan Permukiman Kumuh

\begin{tabular}{|c|c|}
\hline Kriteria & Subkriteria \\
\hline $\begin{array}{l}\text { Kondisi Bangunan } \\
\text { Gedung }\end{array}$ & $\begin{array}{l}\text { Ketidakteraturan Bangunan } \\
\text { Tingkat Kepadatan Bangunan } \\
\text { Ketidaksesuaian dengan Persyaratan Teknis } \\
\text { Bangunan }\end{array}$ \\
\hline $\begin{array}{l}\text { Kondisi Jalan } \\
\text { Lingkungan }\end{array}$ & $\begin{array}{l}\text { Cakupan Pelayanan Jalan Lingkungan } \\
\text { Kualitas Permukaan Jalan Lingkungan }\end{array}$ \\
\hline $\begin{array}{l}\text { Kondisi Penyedia Air } \\
\text { Minum }\end{array}$ & $\begin{array}{l}\text { Ketidaktersediaan Akses Aman Air Minum } \\
\text { Tidak Terpenuhinya Kebutuhan Air Minum }\end{array}$ \\
\hline $\begin{array}{l}\text { Kondisi Drainase } \\
\text { Lingkungan }\end{array}$ & $\begin{array}{l}\text { Ketidakmampuan Mengalirkan Limpasan Air } \\
\text { Ketidaktersediaan Drainase } \\
\text { Ketidakterhubungan dengan sistem drainase } \\
\text { tidak terpeliharanya drainase } \\
\text { Kualitas Konstruksi Drainase }\end{array}$ \\
\hline $\begin{array}{l}\text { Kondisi Pengelolaan } \\
\text { Limbah }\end{array}$ & $\begin{array}{l}\text { Sistem pengelolaan Air limbah tidak sesuai } \\
\text { standar teknis } \\
\text { Prasarana dan sarana pengelolaan air limbah } \\
\text { tidak sesuai standara teknis }\end{array}$ \\
\hline $\begin{array}{l}\text { Kondisi Pengelola } \\
\text { Persampahan }\end{array}$ & $\begin{array}{l}\text { Prasarana dan asarana persampahan tidak } \\
\text { sesuai standar teknis } \\
\text { Sistem pengelolaan persampahan tidak sesuai } \\
\text { standar teknis } \\
\text { Tidak terpeliharanya sarana dan prasarana }\end{array}$ \\
\hline $\begin{array}{l}\text { Kondisi Proteksi } \\
\text { Kebakaran }\end{array}$ & $\begin{array}{l}\text { Ketidaktersediaan prasarana proteksi } \\
\text { kebakaran } \\
\text { Ketidaktersediaan sarana proteksi kebakaran }\end{array}$ \\
\hline
\end{tabular}

$\overline{\text { Sumber : Panduan Penyusunan Kawasan Permukiman Kumuh Perkotaan, } 2015}$

Selanjutnya untuk menentukan bobot prioritas kriteriakriteria yang berpengaruh terhadap terhadap identifikasi kawasan permukiman kumuh digunakan analisis AHP (Analytical Hierarchy Process) dengan menggunakan software pengolah data AHP. Adapun hasil pembobotan tersebut adalah pada tabel 2 .

Tabel 2.

Pembobotan Analisis AHP Identifikasi Kawasan Permukiman Kumuh

\begin{tabular}{lllr}
\hline \hline Kriteria & Subkriteria & Kode & \multicolumn{1}{c}{ Bobot } \\
\hline Kondisi & Ketidakteraturan Bangunan & A1 & 0,021 \\
$\begin{array}{l}\text { Bangunan } \\
\text { Gedung }(0,036)\end{array}$ & A2 & 0,009 \\
& $\begin{array}{l}\text { Bangkat Kepadatan } \\
\text { Ketidaksesuaian dengan } \\
\text { Persyaratan Teknis Bangunan }\end{array}$ & A3 & 0,006
\end{tabular}

\begin{tabular}{|c|c|c|c|}
\hline Kondisi Jalan & Cakupan Pelayanan Jalan & A4 & 0,058 \\
\hline Lingkungan & Lingkungan & & \\
\hline$(0,098)$ & $\begin{array}{l}\text { Kualitas Permukaan Jalan } \\
\text { Lingkungan }\end{array}$ & A5 & 0,019 \\
\hline Kondisi & Ketidaktersediaan Akses & A6 & 0,019 \\
\hline Penyedia Air & Aman Air Minum & & \\
\hline Minum $(0,221)$ & $\begin{array}{l}\text { Tidak Terpenuhinya } \\
\text { Kebutuhan Air Minum }\end{array}$ & A7 & 0,13 \\
\hline Kondisi & Ketidakmampuan & A8 & 0,005 \\
\hline Drainase & Mengalirkan Limpasan Air & & \\
\hline Lingkungan & Ketidaktersediaan Drainase & A9 & 0,058 \\
\hline \multirow[t]{3}{*}{$(0,098)$} & $\begin{array}{l}\text { Ketidakterhubungan dengan } \\
\text { sistem drainase }\end{array}$ & A10 & 0,025 \\
\hline & Tidak terpeliharanya drainase & A11 & 0,012 \\
\hline & Kualitas Konstruksi Drainase & A12 & 0,011 \\
\hline Kondisi & Sistem pengelolaan Air & A 13 & 0,027 \\
\hline & $\begin{array}{l}\text { limbah tidak sesuai standar } \\
\text { teknis }\end{array}$ & & \\
\hline$(0,045)$ & $\begin{array}{l}\text { Prasarana dan sarana } \\
\text { pengelolaan air limbah tidak } \\
\text { sesuai standara teknis }\end{array}$ & A14 & 0,027 \\
\hline \multirow{3}{*}{$\begin{array}{l}\text { Kondisi } \\
\text { Pengelola } \\
\text { Persampahan } \\
(0,406)\end{array}$} & $\begin{array}{l}\text { Prasarana dan asarana } \\
\text { persampahan tidak sesuai } \\
\text { standar teknis }\end{array}$ & A15 & 0,057 \\
\hline & $\begin{array}{l}\text { Sistem pengelolaan } \\
\text { persampahan tidak sesuai } \\
\text { standar teknis }\end{array}$ & A16 & 0,24 \\
\hline & $\begin{array}{l}\text { Tidak terpeliharanya sarana } \\
\text { dan prasarana }\end{array}$ & A17 & 0,202 \\
\hline $\begin{array}{l}\text { Kondisi } \\
\text { Proteksi }\end{array}$ & $\begin{array}{l}\text { Ketidaktersediaan prasarana } \\
\text { proteksi kebakaran }\end{array}$ & A18 & 0,056 \\
\hline $\begin{array}{l}\text { Kebakaran } \\
(0,095)\end{array}$ & $\begin{array}{l}\text { Ketidaktersediaan sarana } \\
\text { proteksi kebakaran }\end{array}$ & A19 & 0,019 \\
\hline
\end{tabular}

Sumber : Hasil Analisis, 2016

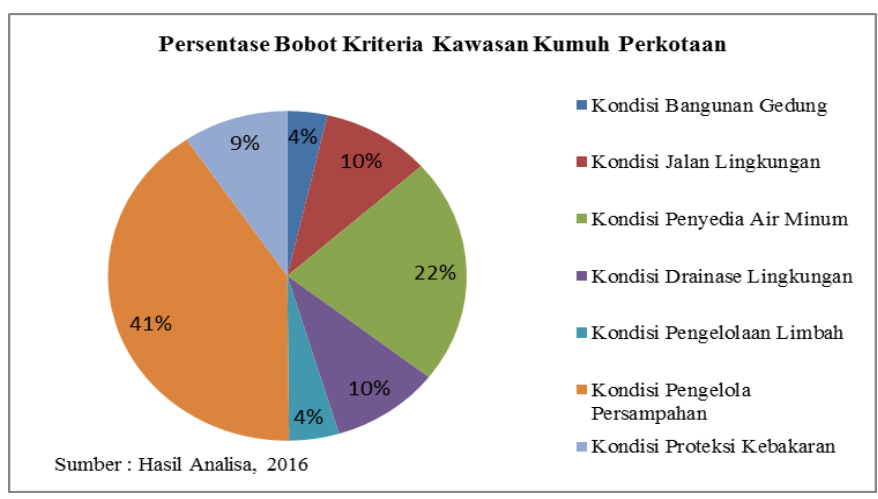

Gambar 1. Persentase Bobot Kriteria Kawasan Kumuh Perkotaan

\section{KESIMPULAN}

Berdasarkan hasil analisis dan pembahasan yang telah dilakukan pada penelitian ini, maka dapat disimpulkan bahwa :

1) Kriteria-kriteria yang sangat berpengaruh dalam penentuan identifikasi kawasan permukiman kumuh di wilayah penelitian adalah kriteria sistem pengelolaan persampahan tidak sesuai standar teknis, tidak terpeliharanya sarana dan prasarana persamapahan, tidak terpenuhinya kebutuhan air minum, cakupan pelayanan jalan lingkungan dan ketidaktersediaan drainase.

2) Berdasarkan derajat pengaruh (bobot) setiap subkriteria untuk identifikasi kawasan permukiman kumuh, dimulai dari subkriteria yang memiliki bobot tertinggi hingga terendah. Adapun subkriteria-subkriteria tersebut antara 
lain :

1. sistem pengelolaan persampahan tidak sesuai standar teknis $\quad(0,240)$

2. tidak terpeliharanya sarana dan prasarana $\quad(0,200)$

3. Tidak Terpenuhinya Kebutuhan Air Minum $\quad(0,130)$

4. Cakupan Pelayanan Jalan Lingkungan $\quad(0,058)$

5. Ketidaktersediaan Drainase $\quad(0,058)$

6. prasarana dan asarana persampahan tidak sesuai standar teknis $\quad(0,057)$

7. ketidaktersediaan prasarana proteksi kebakaran $(0,056)$

8. sistem pengelolaan Air limbah tidak sesuai standar teknis

9. prasarana dan sarana pengelolaan air limbah tidak sesuai standara teknis $\quad(0,027)$

10. Ketidakterhubungan dengan sistem drainase $(0,025)$

11. Ketidakteraturan Bangunan $(0,021)$

12. Kualitas Permukaan Jalan Lingkungan $\quad(0,019)$

13. Ketidaktersediaan Akses Aman Air Minum $(0,019)$

14. ketidaktersediaan sarana proteksi kebakaran $(0,019)$

15. tidak terpeliharanya drainase $(0,012)$

16. Kualitas Konstruksi Drainase $\quad(0,011)$

17. Tingkat Kepadatan Bangunan $\quad(0,009)$

18. Ketidaksesuaian dengan Persyaratan Teknis

Bangunan $\quad(0,006)$

19. Ketidakmampuan Mengalirkan Limpasan Air $(0,005)$

\section{SARAN}

Berdasarkan hasil analisis dan pembahasan yang telah dilakukan pada penelitian ini, maka penulis menyarankan :

1) Setelah dilakukan analisis AHP, sebaiknya dilakukan pemetaan batas pada setiap RT dan RW untuk memudahkan dalam pembuatan peta kekumuhan berbasis RT.

2) Setelah dilakukan analisis AHP, sebaiknya dilakukan perhitungan skoring pada setiap RT.

3) Dengan didapatkan perhitungan skoring pada setiap RT, hasil skoring tersebut dapat ditunjukkan kawasan kumuh perkotaan yang dapat dianalisis kawasan mana saja yang termasuk tingkat kekumuhan ringan, sedang dan berat.

4) Setelah didapatkan hasil klasifikasi tingkat kekumuhan kemudian setiap tingkat kekumuhan di wilayah RT dapat divisualisasikan dalam bentuk peta sehingga lebih mudah dipahami.

\section{DAFTAR PUSTAKA}

[1] Budiharjo, E. (1997). Tata Ruang Perkotaan. Bandung: Alumni. 